\title{
Lacrimal duct obstruction after radioiodine therapy: case report and treatment
}

\author{
Obstrução da via lacrimal após radioiodoterapia: \\ relato de caso e conduta
}

Silvia Helena Tavares Lorena', João Amaro Ferrari Silva²

\begin{abstract}
Iodotherapy represents the radioactive iodine therapy. The beta radiation emitted by radioactive iodine are particles that will be stored in the thyroid tissue destroying cancer cells that were left after surgery (thyroidectomy). It is important to emphasize a possible deleterious effect of therapy which affects the mucosa of the lacrimal system which results in a process of vascular inflammation and scarring producing disorders hypovascular, hypocellular and hypoxic.
\end{abstract}

Keywords: Lacrimal duct obstruction/etiology; Dacryocystitis; Iodine radioisotopes/adverse effects; Case reports

\section{$\underline{\text { ReSUMO }}$}

Iodoterapia representa a terapia com iodo radioativo. A radiação beta emitida pelo iodo radioativo são partículas que irão se armazenar no tecido da tireóide destruindo as células cancerígenas que ainda restaram após a cirurgia (tireoidectomia). É importante enfatizar este possível efeito deletério da terapêutica, a qual afeta a mucosa da via lacrimal, sendo o resultado do processo de inflamação e cicatrização vascular, produzindo transtornos hipovasculares, hipocelulares e hipóxicos.

Descritores: Obstrução dos ductos lacrimais/etiologia; Dacriocistite; Radioisótopos do iodo/efeitos adversos; Relatos de casos

\footnotetext{
1,2 Federal University of São Paulo (UNIFESP), São Paulo/SP, Brazil.
}

Work conducted at the Lacrimal Pathways Unit, Federal University of São Paulo (UNIFESP), São Paulo/SP, Brazil.

The authors declare no conflict of interest.

Received for publication 14/10/2011 - Accepted for publication 1/2/2012 


\section{INTRODUCTION}

$\mathbf{N}$ asolacrimal duct obstruction in adults ${ }^{(1-3)}$ can be classified as primary (which involves a lymphocytic infiltrate culminating in a scarring process) and secondary (due to various situations such as therapeutic irradiation of nasopharyngeal carcinoma and basal cell carcinoma of the inner canthus, radioiodine therapy for thyroid carcinoma, midfacial fractures, leukaemia, sarcoidosis, tuberculosis, trachoma, Down syndrome, Stevens-Johnson syndrome, leishmaniasis, Hansen's disease, lymphoma, plug migration, and iatrogenic).

The clinical manifestations of nasolacrimal duct obstruction are epiphora followed by an inflammatory and infectious process leading to chronic or acute dacryocystitis. The differential diagnosis of dacryocystitis includes: skin abscess, acute anterior ethmoiditis, dermoid cyst, cavernous haemangioma, fibroma, and dacryolithiasis. Mucocele of the lacrimal sac is a chronic dacryocystitis in which the sac increases in size. It would not occur without dacryocystitis. ${ }^{(1-3)}$

Chronic dacryocystitis represents $2-3 \%$ of cases of nasolacrimal duct obstruction. ${ }^{(1-3)}$ According to the literature, the most frequent causes of nasolacrimal duct obstruction are: idiopathic $(59.2 \%)$, congenital $(29.6 \%)$, iatrogenic $(4.5 \%)$, and secondary to radiotherapy $(3.7 \%) .^{(4)}$

Obstruction after radioiodine therapy is due to the presence of sodium-iodide transporters in the mucosa of the lacrimal sac and the nasolacrimal duct, which are areas of anatomic obstruction. The presence of this receptor explains the fibrosis replacing epithelial cells of the lacrimal sac after radioiodine therapy.(5,6)

Radioactive iodine is used in the treatment of differentiated thyroid carcinoma. The aim of treatment is to use the radiation emitted by iodine to destroy cancer cells that remain after surgery (thyroidectomy).

The therapy requires hospitalisation for clinical control and to allow the ingested iodine to be eliminated until radiation levels drop.

Iodine is present in iodised salt found in the diet. Iodine in salt is of great importance because it is an essential nutrient for the thyroid gland. The thyroid is located in the front part of the neck and is responsible for releasing essential hormones for human metabolism such as T3 (triiodothyronine) and T4 (thyroxine). ${ }^{(7-10)}$

Radioactive iodine in the form of sodium iodide is produced by physical processes from iodine found in nature. Because of its similarity to iodine, radioactive iodine is also captured by the thyroid, entering the gland's metabolism. This type of iodine is called radioactive because it releases two types of radiation: gamma radiation (similar to X-rays) and beta radiation, which is used to fight cancer cells that remain in the thyroid. Beta radiation consists of particles that are stored in thyroid tissue, destroying cancer cells. ${ }^{(11,12)}$

Systemic side effects have been reported with high doses. There have been reports of obstruction of the lacrimal system in patients undergoing radioiodine therapy, drawing attention to a possible adverse effect of the therapy.

\section{Case Report}

We report a case of bilateral nasolacrimal duct obstruction in a 42-year-old white female patient. The patient was a married housewife born in Garanhões (Piaui, Brazil) and living in São Paulo who underwent total thyroidectomy due to papillary thyroid carcinoma. She was submitted to radioiodine therapy, and after 2 years she presented with epiphora in both eyes.

Examination showed a 1.0 vision in both eyes, without proptosis (Figure 1) and with preserved extraocular muscles.

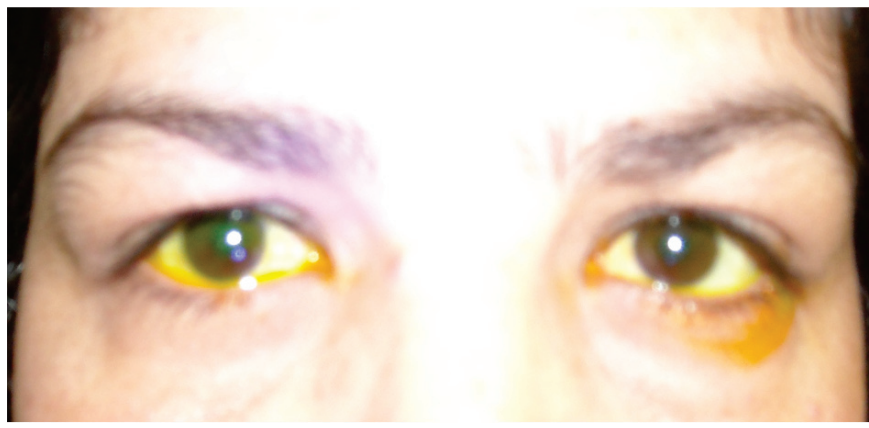

Figure 1. Appearance of the patient's face.

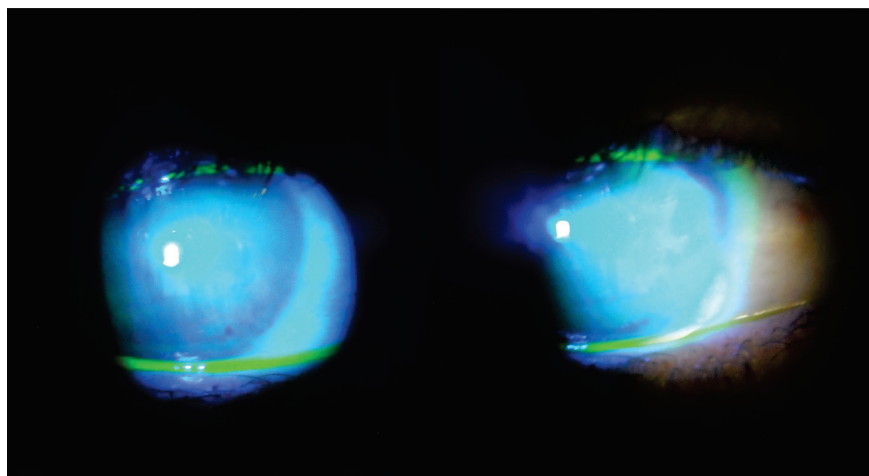

Figure 2. Milder test found +2 in both eyes.
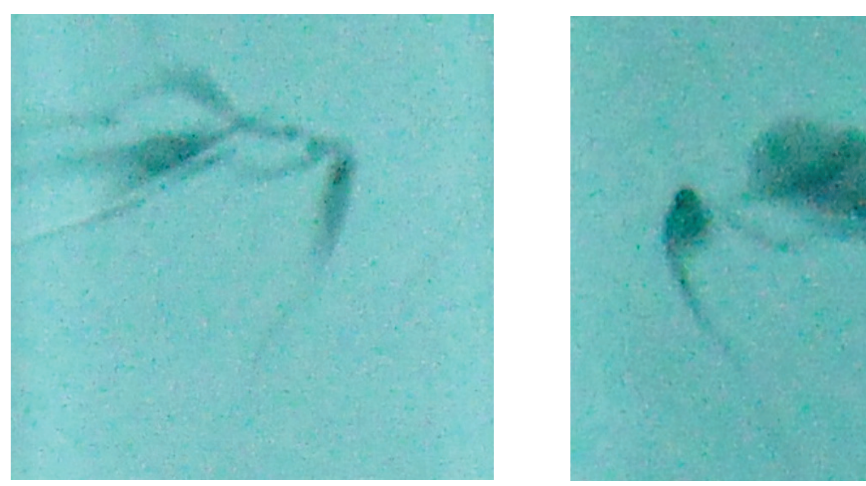

Figure 3. Dacryocystography of both eyes.

Biomicroscopy showed no bulbar conjunctival hyperaemia or anterior chamber reaction, but found a reflux of mucopurulent discharge in both eyes after compression of the medial part of the orbit. Milder test: RE, $+2 ; \mathrm{LE},+2$ (Figure 2).

Dacryocystography with digital subtraction showed a complete obstruction at the level of Krause's valve in both eyes (Figure 3).

The patient will undergo bilateral external dacryocystorhinostomy.

\section{Discussion}

In humans, the nasolacrimal ducts are an integral part of the lacrimal system and are responsible for transporting tears from the ocular surface to the inferior nasal meatus. Proper functioning of the lacrimal sac and nasolacrimal duct depends on the underlying mucosa and muscle layer. Tear flow through the lacrimal sac and nasolacrimal duct is highly dependent on interactions between mucosal mucins, microvilli, and tear fluid. ${ }^{(13-15)}$

The lacrimal sac and nasolacrimal duct have a different pattern of mucin gene expression compared to the ocular surface. 
Immunohistochemistry shows that the epithelium of the lacrimal sac and nasolacrimal duct produces MUC5B and -7 and, to a lesser degree, MUC5AC and -2 . The pattern of epithelial mucin seems to change from the ocular surface toward the lacrimal sac. The nasolacrimal duct was found to produce MUC5B. ${ }^{(13-15)}$

The diversity of mucins in the lacrimal sac and nasolacrimal duct may be related to improved tear transportation and antimicrobial effects. The reduced levels of mRNA for secretory mucins found in functional dacryostenosis supports the hypothesis that mucins facilitate tear flow through the nasolacrimal duct. ${ }^{(13-15)}$

The Na+/I-symporter (NIS) is a glycoprotein that promotes iodide uptake by the thyroid gland and several other tissues. Nasolacrimal duct obstruction has been reported as complication of radioiodine (I-131) therapy in the treatment of thyroid cancer. NIS-producing cells were absent and fibrosis was observed in the nasolacrimal ducts of patients treated with I-131, suggesting that active iodine uptake mediated by NIS could be responsible for damage to the nasolacrimal duct. ${ }^{(16-18)}$

The presence of NIS in columnar epithelial cells of the lacrimal sac and nasolacrimal duct, sites where obstruction tends to occur in patients treated with radioiodine therapy, suggests that NIS may mediate active iodine uptake in these tissues and may be involved in the pathogenesis of lacrimal obstruction ${ }^{(18)}$.

While high therapeutic doses of radioiodine for thyroid cancer ablation are generally well tolerated, the therapy is associated with certain adverse effects. Ophthalmic complications of therapy include conjunctivitis, dry eye and epiphora ${ }^{(18-26)}$.

Severe complications include necrosis and secondary infection of previously irradiated tissues. Acute effects usually involve the oral mucosa. Chronic effects affect the bones and other mucous membranes, including the lacrimal sac and nasolacrimal duct mucosa, and result from inflammatory and scarring processes, leading to hypovascular, hypocellular, and hypoxic disorders ${ }^{(27)}$.

\section{ReferenCES}

1. Linberg JV. Pathology of nasolacrimal duct obstruction. In: Linberg JV. Lacrimal surgery. New York: Churchill Livingstone; 1988. p. 169-200.

2. Tucker N, Chow D, Stockl F, Codère F, Burnier M. Clinically suspected primary acquired nasolacrimal duct obstruction: clinicopathologic review of 150 patients. Ophthalmology. 1997;104(11): 1882-6.

3. Bernardini FP, Moin H, Kersten RC, Reeves D, Kulwin DR. Routine histopathologic evaluation of the lacrimal sac during dacryocystorhinostomy: how useful is it? Ophthalmology. 2002;109(7): 1214-7; discussion 1217-8. Comment in Ophthalmology. 2003; 110(12):2434-5; author reply 2435-6.

4. Santos FP, Souza TV,Abreu CB, Silva MLS, Balieiro FO, Pignatari SSN, Stamm AC. Dacriocistorrinostomia endoscópica transnasal: técnicas e resultados. Rev Bras Otorrinolaringol. 2010;76(5 Supl):197.

5. Classics in oncology. Effects of radiation on normal tissues: Shields Warren M.D. CA Cancer J Clin.1980;30(6):350-5.

6. Riley PA. Free radicals in biology: oxidative stress and the effects of ionizing radiation. Int J Radiat Biol.1994;65(1):27-33.

7. Ambrosetti MC, Colato C, Dardano A, Monzani F, Ferdeghini M. Radioiodine ablation: when and how. Q J Nucl Med Mol Imaging. 2009;53(5):473-81.

8. Reiners C. Radioactivity and thyroid cancer. Hormones (Athens). 2009;8(3):185-91. Review.

9. Haugen BR. Patients with differentiated thyroid carcinoma benefit from radioiodine remnant ablation. J Clin Endocrinol Metab. 2004;89(8):3665-7. Comment on J Clin Endocrinol Metab. 2004;89(8):3668-76.
10. Bonnema SJ, Nielsen VE, Hegedüs L. Long-term effects of radioiodine on thyroid function, size and patient satisfaction in non-toxic diffuse goitre. Eur J Endocrinol. 2004;150(4):439-45.

11. Braga-Basaria M, Ringel MD. Clinical review 158: Beyond radioiodine: a review of potential new therapeutic approaches for thyroid cancer. J Clin Endocrinol Metab. 2003;88(5):1947-60.

12. Parthasarathy KL, Crawford ES. Treatment of thyroid carcinoma: emphasis on high-dose 131I outpatient therapy. J Nucl Med Technol. 2002;30(4):165-71; quiz 172-3.

13. Paulsen FP, Thale AB, Hallmann UJ, Schaudig U, Tillmann BN The cavernous body of the human efferent tear ducts: function in tear outflow mechanism. Invest Ophthalmol Vis Sci. 2000;41(5):965-70.

14. Watanabe H. Significance of mucin on the ocular surface. Cornea. 2002;21(2 Suppl 1):S17-22.

15. Perra MT, Serra A, Sirigu P, Turno F. A histochemical and immunohistochemical study of certain defense mechanisms in the human lacrimal sac epithelium. Arch Histol Cytol. 1995;58(5):517-22.

16. Vadysirisack DD, Chen ES, Zhang Z, Tsai MD, Chang GD, Jhiang SM. Identification of in vivo phosphorylation sites and their functional significance in the sodium iodide symporter. J Biol Chem. 2007;282(51):36820-8.

17. Vadysirisack DD, Venkateswaran A, Zhang Z, Jhiang SM. MEK signaling modulates sodium iodide symporter at multiple levels and in a paradoxical manner. Endocr Relat Cancer. 2007;14(2):421-32.

18. Morgenstern KE, Vadysirisack DD, Zhang Z, Cahill KV, Foster JA, Burns JA, et al. Expression of sodium iodide symporter in the lacrimal drainage system: implication for the mechanism underlying nasolacrimal duct obstruction in I(131)-treated patients Ophthal Plast Reconstr Surg. 2005;21(5):337-44. Comment in Ophthal Plast Reconstr Surg. 2007;23(6):496.

19. Alexander C, Bader JB, Schaefer A, Finke C, Kirsch CM. Intermediate and long-term side effects of high-dose radioiodine therapy for thyroid carcinoma. J Nucl Med. 1998;39(9):1551-4.

20. Solans R, Bosch JA, Galofré P, Porta F, Roselló J, SelvaO'Callagan A, Vilardell M. Salivary and lacrimal gland dysfunction (sicca syndrome) after radioiodine therapy. J Nucl Med. 2001;42(5):738-43

21. Shepler TR, Sherman SI, Faustina MM, Busaidy NL, Ahmadi MA, Esmaeli B. Nasolacrimal duct obstruction associated with radioactive iodine therapy for thyroid carcinoma. Ophthal Plast Reconstr Surg. 2003;19(6):479-81.

22. Brockmann H, Wilhelm K, Joe A, Palmedo H, Biersack HJ. Nasolacrimal drainage obstruction after radioiodine therapy: case report and a review of the literature. Clin Nucl Med. 2005;30(8):543-5.

23. Burns JA, Morgenstern KE, Cahill KV, Foster JA, Jhiang SM, Kloos RT. Nasolacrimal obstruction secondary to I(131) therapy. Ophthal Plast Reconstr Surg. 2004;20(2):126-9.

24. Sakahara H, Yamashita S, Suzuki K, Imai M, Kosugi T. Visualization of nasolacrimal drainage system after radioiodine therapy in patients with thyroid cancer. Ann Nucl Med. 2007;21(9):525-7.

25. Tsang RW, Brierley JD, Simpson WJ, Panzarella T, Gospodarowicz MK, Sutcliffe SB. The effects of surgery, radioiodine, and external radiation therapy on the clinical outcome of patients with differentiated thyroid carcinoma. Cancer. 1998;82(2):375-88.

26. Paulsen FP, Corfield AP, Hinz M, Hoffmann W, Schaudig U, Thale $\mathrm{AB}$, Berry M. Characterization of mucins in human lacrimal sac and nasolacrimal duct. Invest Ophthalmol Vis Sci. 2003;44(5):1807-13.

27. 'Bakheet SM, Hammami MM, Powe J, Larsson S. Radioiodine uptake in the head and neck. Endocr Pract. 2000;6(1):37-41.

\section{Corresponding author:}

Silvia Helena Tavares Lorena

Rua Flórida $n^{\circ} 1404$ - Brooklin

CEP: 04561-030 - São Paulo - SP, Brazil

E-mail: silvia.helenatavareslorena@yahoo.com.br 